\title{
Labor Market Flexibility: Advantages for Workforce or Threat?
}

\author{
Alih Aji Nugroho•
}

\begin{abstract}
Labor Market Flexibility (LMF) which is supported by the law of supply and demand are considered capable of creating an efficient labor market. As well as apprenticeship programs were considered to improve the quality of the labor force which can suppress the number of unemployed. Whether the application of LMF can be a positive impact like as imagined by its proponents? This is the result of research that seeks to see the dynamics of industrial relations faced by the workforce under the LMF system and dismantle the neoliberal project of the apprenticeship system. The study was conducted during September-November 2016 in the industrial area of Bekasi. The study used a descriptive qualitative approach. Collecting data through participatory research or live in. Searchable data sources using methods of a snowball effect. In the end, this study involved seven trade unions, six companies, two foundations labor brokers, three government agencies, 35 workers (10 contract workers, 10 workers outsourcing, and 15 workers apprenticeship) and three labor activists. The result is the implementation of contract system and outsourcing many violate the rules. In the industrial area of Bekasi composition flexible workforce of more than $50 \%$ of the total workforce. And under the LMF system occurs bureaucratization in industrial relations. In addition, LMF policy does not reduce unemployment but only rotate unemployment. and the apprenticeship system is expected to increase human resources in the labor force application only used by the owners of capital to get cheap labor.
\end{abstract}

\section{Keywords:}

industrial relations; labor market flexibility; labor force; outsourcing; apprenticeship

\section{Introduction}

This Paper seeks to provide a different analysis of the lebor market flexibility (LMF) policies. Its proponents assume that by implementing LMF will create a harmonious interaction labor markets based on market mechanisms. So that conditions can be the benefit of the workers. Instead, the application of LMF actually poses a threat to workforce and the all workers.

The dynamics of industrialization and labor system in Indonesia cannot be separated from global conditions. To analyze the issue of labor in a State cannot be separated from the global analysis. As Berquist discloses (Hadiz,
1997, p. 7) if you want to see and analyze labor in a place cannot be separated from the analysis of the system (capitalism) of the world (Worldsystem Analysis). In the era of globalization, consumers have the freedom to the choice of goods in the market. The implication is that the companies are competing against the price of production so that the selling price can be reduced. the global capitalist wants production conditions to become more flexible (flexibility production process) to make it easier to respond to the market demand (aggregate demand). Frederic Deyo \& Richard Donner (2001) describe the desired condition is "global buyers stress competitive price, good quality, quick

- STIA LAN Jakarta

Email: alihnugroho@gmail.com. 
delivery time, and heightened responsiveness to changing demand requirements."

Juliawan (2010) explains that the incident cannot be separated from over production from global companies thus creating a competitive market. Companies are trying to cut production factors to create a large marginal revenue. The most easily manipulated production factor to create minimum cost is labor. In the early 1980s after the Washington Consensus, neoliberalization was seen as a way to stabilize the world economy, preceded by America and Britain and then spread throughout the world. The agenda of labor market liberalization becomes the road, the embodiment is a flexible labor market or better known as Labor Market Flexibility (LMF).

One of the goals of labor market liberalization in Indonesia since 2003 is the effort to create an ideal industrial relation like imagined of the liberal. Labor Market Flexibility (LMF) is the key to the idea (Caraway et al., 2014). In the LMF, it is conceivable that workers are free to allocate their services to respond to turnover of relative wage change opportunities, while companies are free to adjust workers in response to turnover of relative profit opportunities. In the labor market, the free interaction between the employee and the employee is seen as a necessary condition for economic growth. The free labor user is looking for the workforce in accordance with the rational needs of the users, while the free workforce selects the labor users in accordance with the rational needs of the workforce (Purdy, 1988, p. 5-6).

In the above framework, collective bargaining by trade unions, strict implementation of the rules of recruitment and dismissal of workers, severance pay, minimum wage and so on is considered a price distortion because it is considered to restrict freedom between employers and workers (Islam, 2000, p. 3-4). If the state intervenes too much in the labor market, the labor market is called too 'rigid' in contrast to the minimal 'flexible' labor market that plays the role of the state and surrenders market mechanisms as the prime mover of working conditions. Only with such a mechanism, an efficient job market can materialize. The argument is the basis of the International Monetary Fund (IMF) campaign to promote LMF policy in the world. IMF working paper (2012) mentions "that policies (read: labor market flexible) that enhance labor market flexibility should reduce unemployment".

LMF is claimed to be a way to improve the economy of a country by reducing unemployment (Livingstone, 1998). Flexible working conditions are considered to reduce the number of unemployed because it can be absorbed by the contract system, outsourcing, and internships. Contract and outsourcing systems are considered capable of absorbing the workforce quickly because it is connected to the needs of the workforce. Much research has been undertaken to reinforce the need for flexible labor policies that compare the number of unemployed before and after the policy is enacted (Hefeker, 2001; Lorenzo et al.,2012; Paul, 1994).

The apprenticeship system is considered capable of reducing unemployment because this system can improve the quality of the workforce. Productive age, which is a graduate from high school or equally, by following the internship program is expected to increase knowledge and skills. In essence, low labor education in Indonesia is claimed to be a factor of low productivity and causes the labor force not to be absorbed in the world of work.

However, the liberal ideal of ideas is not easy to find its manifestation in the field. Studies conducted by Juliawan (2010), for example, the existence of LMF policy in Indonesia instead of making industrial relations become like the imagined of liberal, free and competitive, even led to the actors who dominate power over the workers. Both formal and informal actors 
participate in the LMF economic chain. Taking a study in Tangerang and Medan, Juliawan explains convincingly that LMF policies are not like the liberal image that the labor market is following the market mechanism. But it turns out that the policy encounters its own paradox, generating an economic intermediary that even distorts the market mechanism.

It should be acknowledged that the Juliawan (2010) study contributes significantly to providing an overview of established industrial relations following flexible labor market policies implemented, especially in the application of outsourcing systems. But the study has its own limitations. First, Juliawan has not yet recorded a massive new system used in the flexible labor market policy of apprenticeship systems. Although the apprenticeship system is also contained in Law No. 13. 2003 but its massive use in early 2016. Friday 13 December 2016 Indonesian President Jokowi declared apprenticeship system at International Industrial Area City (KIIC) Karawang. Followed by Bekasi industrial area declaring apprenticeship program in April 2017. Secondly, Juliawan (2010) has not described in detail the LMF's influence on the labor force. Is the LMF proven to work in accordance with the ideal imaginated of its proponent? Or even a threat to the labor force in Indonesia. Third, Juliawan's studies in Medan and Tangerang in the 2009 medium missed the best momentum in the massive labor action in Indonesia that is often known as "grebek pabrik". The "grebek pabrik" action took place in Bekasi industrial area where tens of thousands of workers took place in the medium of 2012 bringing the main issue of eliminating the contract and outsourcing system (LMF). So Bekasi became a lucrative laboratory to become a research area for key questions: (1) Can Labor Market Flexibility policy in Indonesia reduce unemployment? (2) How does Labor Market Flexibility policy affect the workforce in Indonesia?

\section{Literature Review \\ Labor Market Flexibility}

In a recent debate devoted to The 'Labour Question' in contemporary capitalism (Chhachhi, 2014), the sociologist Jan Breman and the labour historian Maroel Van der Linden (Bremen, 2014; Linden, 2014) in Betti (2016, p. 1) explicity addressed precarious work and its role in past and present capitalism. They explicity questioned the "standard employment relationship" as the norm of capitalism, while conceptualized precarity, informality and insecurity, no longer addressed as exceptions, as the real norm of global realitionship in the long run.

The global convergence in labour relations is also one of the pillars of the analysis proposed by Sara Mosoetsa, Joel Stillermann and Chris Tilly (2016) in their introduction to a special issue devoted to precarious labour in global perspectives. The latter, thanks to a historical-sociological perspective, investigated forms of precarity in South Africa, India, Mexico, China, Italy, paying specific attention to the intersection with the process of informalization and forms of informal work. Mosoetsa, Stillermann and Tilly not only conceptualize precarious work as the norm of capitalism, but interpret the recent spread of precarious work as a "return" after the interruption that had occurred during Fordism in several, but not all, countries. Like Neilson and Rossiter, they stressed that precarious work has had indeed a long existence in the Global South but in different shapes and forms.

Other recent historical research has shown the existence of forms of work, which today we label precarious, in different phases of capitalism, questioning also from a long duré perspective the exceptionality of job precarity and its exclusive relationship with Post-Fordism and Neoliberalism (Van Der Linder, 2014). The perpetuation between the late-nineteenth and the mid-twentieth centuries of rather similar forms of precarious work, 
in spite of the changes in the organisation of work and production, clearly emerges from the studies conducted by Sophie Beau (2004) on the department stores of Lyons or by Augusto De Benedetti on glove manufacturing in Naples (2006). In this perspective also lies the work of Marc Leleux (2015), who retraces forms of precarious work in the industrial development experienced by Northern France from the mid19th century to the early 20th century. Beyond Western countries and free wage labour, De Vito (2017) has conceptualized precarity in regard to late colonial and post-colonial Spanish America, looking at the degree of flexibility and precariousness experienced by various kinds of unfree workers (i.e. convict labourers, chattel slave). The most policy was implementated precarious working relations is a Labor Market Flexibility (LMF).

Labor Market Flexibility policies are gaining popularity in Europe after the fordist era that guarantees labor (rigid). Job security such as labor law, welfare, and industrial relations is allegedly the basis of increasing unemployment in Europe (Barbieri, 2009). The economic downturn also scapegoats the rigid policy. The inability of the private sector to reduce the number of employees and the capacity of employees at a time when the European economy weakened because of the decline in oil prices at that time was considered to be the cause of the slow growth of the economy (Gilles, 1996; Grimsaw, 2003).

In Industrialized Countries (the US and Europe) the flexible labor market agenda is a proposal of the OECD, the World Bank, and the IMF. Gerry Rodgers (2007) said that the three institutions suggest the deregulation of labor market policies to be flexible in order to improve the investment climate. Rodges uses labor protection data (protection to labor) with the number of unemployed. The conclusion is the same as the study of World Bank and IMF that is the higher protection against workers making high unemployment rate. The emergence of outsourcing work system is one of the consequences of the specialization of work. With the specialization of work will facilitate the use of outsourcing work system because it looks the difference between the main business and supporting business (Mather, 2004). But problematic is the company can according to the will defines the main business and support.

The new economic orthodoxy neoliberalism - emphasized a vision of efficiency delivered by self-regulating markets, with prices ensuring the correct al- location of resources. The role of the state was to maintain monetary and fiscal stability. In effect, this new orthodoxy replaced the Keynesian welfare state, which promoted full employment by stimulating demand in the decades after World War II. The new orthodoxy marked a structural transformation in labor market policy making in many parts of the world. States began to use macroeconomic policy, essentially monetary policies, to control inflation rather than to guarantee full employment, which was now relegated to the domain of microeconomic policy enacted through institutional and regulation reforms. The new ap- proach provided a justification for favoring "productivity" over "employment." In the words of Jeffrey Harrod and Robert O'Brien, "it became legitimate to pro- mote unemployment to enhance productivity, to reduce the workforce to in- crease shareholder and executive salaries." Indeed, labor security, which was held out as one of the main objectives of postwar development, was now seen as an obstacle to economic productivity and national competitiveness (Juliawan, 2010).

In today's globalized economy, a combination of exogenous factors, i.e., transformed markets, external market liberalization, and accelerating techno- logical change, also contribute to the pressures for flexibility. Many industries have generated global oversupply, creating what is called buyers' markets. In such markets, customers 
enjoy expanded choices and competitive markets. As Frederic Deyo and Richard Doner describe it, "global buyers stress competitive price, good quality, quick delivery time, and heightened responsiveness to changing demand requirements." These factors put pressures on industries to make the supply side equally flexible. In the developing world the pressures for cost and quality are transferred to local companies through the opening of ex- ternal markets. East Asia in particular has seen a rapid development in the direc- tion of opening their external markets. Many countries in the region have moved toward tariff reductions as a condition of membership in the World Trade Organization (WTO) and participation in the Asean (Association of South East Asian Nations) free trade agreement. In export-oriented textile, clothing, and footwear industries, in particular, pressure builds on firms to respond quickly to the volatile demand for a wide range of products. And this requires relatively short production runs.

Labor market flexibility according to Rubery \& Grimshaw (2003) is the ability to adapt and respond to change. Then Rodgers (2007) and Atkitson (1984) distinguishes the flexibility of the labor market into several dimensions. The first, is employment protection, which is related to the work status of the worker, the variation of work type and the standard protection that follows. The point on the rigid labor policies necessarily permanent status. Second, wage flexibility is freedom in determining the minimum wage of workers with the coordination of trade unions and employers. Here the workers have to fight with the owners of capital to determine the minimum wage. Third, Internal or Functional Flexibility, is a company's ability to organize and reorganize the internal production processes and the labor used to improve productivity and efficiency. Examples are the flexibility of working time, type of work, the skill required or technical changes. More detail is the flexibility of the company to manage the production process becomes more efficient including the number of workers. Fourth, supply-side flexibility is flexibility in working even in family hours and vice versa. That is, there is "discretion" in using work time to meet the family, but vice versa, when needed at the company must be ready to leave family times.

\section{Labor Market Flexibility in Indonesia}

Through Law No. 13/2003, industrial relations in Indonesia has become more flexible. And they are three LMF mechanisms that will be the focus of this paper. First, the enactment of the Perjanjian Kerja Waktu Tertentu (PKWT). With PKWT, companies may hire contract laborers for certain types of work within a certain time. Broadly, agreements in a given time can also include laborers with monthly, weekly, and casual laborers in this category. Although indeed in some aspects have significant differences. In this paper, the object of analysis is the contract laborer or PKWT. In this mechanism, contract labor does not get the rights as a permanent worker so it relieves the burden of the entrepreneur (Tjandraningsih, Herawati, and Suhadmadi, 2010). Second, the enactment of the outsourcing system. In this case, the company may submit part of the execution of work to other companies through employment contracts or the provision of services of workers/labor which is made in wrote. Third, the apprenticeship system. The internship system can be included in the LMF mechanism because it satisfies all four dimensions of the system. Basically, the apprenticeship system is used to get workers with a certain time. These three mechanisms represent the four dimensions of LMF mentioned by Atkinson (1984) and Rodgers (2007).

The implication of outsourcing implementation is that many companies break the employment relationship with their workers to be further recruited back through 
labor services companies (outsourcing workers) (Nugroho, 2016). Employers with the goal of efficiency feel safe if the workers who work for them are workers in a labor service company. With this mechanism, the one responsible for the outsourced laborer is a private employment agencies (Nugroho, 2018). In the opportunity provided by this new law, private employment agencies have sprung up to take advantage of unprotected workers.

It is wrong to imagine the operation of private employment agencies in Indonesia having similarities with their counterparts in the advanced capitalist countries. In the midst of still dominant patron-client politics where informal networks still play a crucial role (Nordholt, 2004; Sidel, 2004), including in economic affairs, the implementation of flexible labor markets in Indonesia has specific characteristics. Private employment agencies often become more efficient (in their internal affairs) when collaborating with networks of informal actors in recruitment and disciplining workers. In this connection, the term "informal actor" refers to two groups (Juliawan, 2010, p. 40). The first group is a social organization based on religious identity and locality such as youth organizations, recitation groups and martial arts groups. Other informal actor groups are prominent individuals who play roles as religious leaders, village heads or RT heads and local strongmen (thugs). Both categories of informal actors gain strength from two different, albeit interrelated sources. The first source is a patronage network that was treated since the Suharto era, namely the military, local bureaucrats, political party leaders, businessmen, criminals (gangsters), religious leaders and traditional leaders (Nordholt, 2004, p. 48). Other sources mainly deal with politics after the first democratic elections of 1999 and decentralization which gives greater opportunities for mafia networks and local clans to accumulate power (Sidel, 2004 , p. 67). What is referred to as 'local bosses' by Sidel is contrary to the concept of patron client or 'local strong man' proposed by Migdal (1988). If Migdal believes that local strongmen are the main cause of capitalist accumulation in developing countries, Sidel with his comparative studies in the Philippines, Thailand and Indonesia shows that the network of local bosses "... has the capacity to facilitate and benefit from the expansion of market relations and the process of industrial growth in their respective areas of authority" (Sidel, 2004, p. 53).

With the complexity and special character of Indonesia's economic development, it is interesting to see the application of LMF in Indonesia. Broadly speaking, there are two LMF mechanisms that will be the focus of discussion in this paper. First, the contract work and outsourcing system. Second, the internship system. Both of these mechanisms have represented the four dimensions of the LMF mentioned by Atkinson (1984) and Rodgers (2007). The analysis will focus on how the flexible work system is a threat to the workforce. As well as any LMF mechanism commonly found in the field which is a threat to the workforce.

\section{Methods}

Research conducted in this paper using a qualitative approach. To see how the LMF poses its own threat to the workforce, an indepth interview is conducted on LMF workers. What are the problems that often arise and how LMF impacts on the bargaining position of the workforce. In addition to seeing if LMF can reduce the unemployment rate then analyzed the related data.

Data collection for this study combines a number of qualitative methods such as ethnography, participant observation, deep semi-structured interviews, group discussions, and policy studies. The object of research is actors concerned with the results of a search through the snowball technique. The result, 
interviews were conducted on flexible labor who work at these companies (PT HSJ, Trimitra, Tristar, Nanbu Plastics, Indofood, Bevanda Mustika, Mayora, PT Buana), Two Privat Employment Agency (LPK Mardizu and LPK Multi Prima Indoraya Bekasi Training Centre), Department of Manpower and Transmigration (Disnaker), DPRD of Bekasi, labor (10 contract labors, 10 internshiplabors, 5 permanent labors). (Danial Indrakusuma from Partai Perjuangan Rakyat, and activists from PEMBEBASAN), trade union officers (GSPB, SGBN, KASBI, F-SEDAR, SBBM, FSPMI, SPSI), 2 Bureaucrats from Disnaker District of Bekasi, and 2 staf ahli from DPRD from FSPMI.

Data were collected from September to November 2016. Researcher stays and spend a lot of time in Bekasi Industrial Area with the live-in way at the secretariat of the union and move to the flexible laborer's houses. Researchers also are not uncommon attend the meetings conducted of labors, in the demonstration conducted by the unions, and in the confrontation events that occurred in the field.

\section{Results and Discussion}

\section{Bureaucratization in the Industrial Relations}

Bekasi District included in the administrative area of West Java Province. Bekasi District an area with the largest industrial area in Southeast Asia with a total number of the company; small until big companies added with UMKM 5908 (Data from Disnaker Kab. Bekasi 2014). If the company has taken only in small, medium and large scale without UMKM then the number 2,628 spread over 9 Industrial areas. Industrial areas are spread over 4 different districts. Nine industrial zones are I Jababeka Industrial Estate, Jababeka II, III Jababeka, MM2100, East Jakarta Industrial Park (EJIP), Kawasan Bekasi Fajar, Lippo Cikarang, BIEE and Delta Mas Industrial Area.

According to data available at the Department of Manpower and Transmigration
(Disnakertans of Bekasi District), in 2012 from 9 Industrial areas in Bekasi there are 230,041 of laborers. From the data Disnakertrans of Bekasi District, the number of laborers with specific time employment agreement (contract labor) in 2016 reached 47,932 people. While for the number of outsourced labor, and internship there is no data until this day. The performance of Disnakertrans in recording and archiving is still bad. This is ironic because Disnakertrans are located in the largest industrial area in Southeast Asia.

To get the validity from the data of distribution the number of contract laborers, it can be seen from the official data of the Labour Union. Data from the Federation of Metal Workers Union (FSPMI) based in the branch of Bekasi, showed 91 large companies there is SPMI union. The number of these companies are the companies that there are SPMI union and have recorded the number of their contract laborers. The company that already recorded the number of their contract laborers only 91 companies from a total of 313 companies in SPMI union. But from these data can be known how much the number of contract laborers, could even be said that the data released by Disnakertrans is too little and not valid. From the 91 companies with total 58,694 of their laborers consists of 28,564 laborers with contract status and 30,130 permanent laborers. Means that there are $48.6 \%$ laborers with contract labor system, almost equal numbers with permanent laborers.

From the number of contracts, laborers are nearly $50 \%$ of the total laborers in the industrial area of Bekasi can be concluded that the employers are trying to use laborers who are not permanent so it can be easily replaced with new productive laborers. Besides that, the control of employers for the laborers is becoming stronger. Because of the limited time employment contract, if the laborers do not obey the employer then it will not be extended its work. Evident from cases reported by the 
laborers to Disnaker average of dealing with the unilateral layoffs undertaken by employers. Theoretically, the vulnerable job such as contracts laborers offered by Guy Standing (2011) called with the precariat, is the working class who are vulnerable and fragile in the sense of an uncertain future.

As disclosed by Abi (not his real name), a contract laborer at the packaging department in PT Indofood who was dismissed unilaterally by the company, there is no future guarantee for contract laborers. This happened because there is no specific regulation regarding the certainty of appointment from contract laborers into permanent workers. Abi said:

"There is no default setting about criteria such as what should be done so that contract laborers appointed as permanent workers. Though I during the contract period of two years is never one single time absent from work without explanation. Even sometimes when I was sick, I keep still working so that I rated well by my supervisor. But in fact when the contract period almost exhausted there is no appointed to become permanent employees. Whereas at the beginning I worked, my supervisor told me the important thing is work harder and never makes a mistake so will be appointed as permanent employees. But the reality was different, and many who suffer like me in this company. In Indofood itself, I know there are about 1,500 people are contract laborers."

This findings about the industrial relation of the outsourcing system is correspond to the study conducted by Juliawan regarding the private labor service provider who cooperated with the informal actors in recruiting labor. But the differentiation and focus of this writing are the outsourcing systems that make industrial relations becomes very bureaucratic. Bureaucratization occurred in industrial relations. The use of the term refers to the bureaucratic character that convoluted (red tape). Because occurs throwing-responsibility between the company-users service with the service provider if there are problems with the laborers. As stated by Henry, one of the outsourced workers in PT. X:

\begin{abstract}
"I became a labor outsourced already 9 years, whereas according to the rules of the law are not allowed and void legally I automatically become permanent workers. But when I reported to management then they told me to complain to the foundation. When I spoke with the chairman of the foundation, he said that it was my own business with the company. Well, then I was so confused where would to go."
\end{abstract}

\section{The Rise of Internship System that is Vulnerable to Violations}

Since 2009 to November 2016 the domestic apprenticeship program has been attended by 169,317 thousand participants (Kemenakertrans, 2017). The details are 13,053 apprentices in 2009, 14,006 apprentices in 2010, 21,088 apprentices in 2011, 23,071 apprentices in 2012, 24,709 apprentices in 2013, 26,367 apprentices in 2014, 26,437 interns in 2015 and 20,586 interns by November 2016. As for the national apprenticeship program, which begins in 2017 , it will be followed by approximately 163,000 interns.

Bekasi Industrial Estate does not escape the "target" apprenticeship system, April 2017 Minister of Manpower and Transmigration opened a national apprenticeship program. Noted, there are as many as 1019 students who graduate SMK / SMA who follow this program. From the raw data can be estimated that there are approximately 400,000 workers with apprentice status in Indonesia.

The basis of the legitimacy of the apprenticeship system is the education of the labor force in Indonesia is still low. So it takes 
a container that can accommodate high school graduates to transition before entering the real world of work. Apprentice work is considered to be the ideal transitional place because the workforce can improve the quality and can adjust to the world of work. So with the training of the internship then the labor productivity is no longer low.

Promotion of the apprenticeship system has at least two objective bases, (i) to enable the workforce to compete globally and reduce unemployment, (ii) to bridge between graduate schools that do not yet have the skills appropriate to the company's needs (see further Buechtemann, Schupp and Soloff 1994).

The apprenticeship system in Indonesia is regulated in Manpower Law No. 13/2003. How, according to Permenaker No. PER. 22/MEN/IX/2009 apprentices should get a maximum of $25 \%$ theory and $75 \%$ minimal practice directly. Apprenticeship period of 1 year working through integrated cooperation between work training institute (LPK) with the company where work. However, occurrences in the field about the internship is much different from that mandated by the Labor Law. From the first day of internship laborers entering and working as normal as other workers. Almost all the internship laborers work extra hours (lembur). There is no job security or social security that obtained by the internship laborers. In interns in the regulations do not recognize salaries or wages, but the language used was the pocket money. The company is not obligated to hire internship laborers in accordance with the applicable UMK. And there is no minimum limit pocket money given to internship laborers. So in short, whatever pocket money given to interns during the participants do not mind, it is considered legally valid.

According to Saiful (the chairman of Trade Unions of PT Nanbu) explains that in the working factory there was a trend that wants to reproduce internship laborers. The first month of enforced laborers internship in PT Nanbu began in January 2016 as many as 30 people. In October 2016 the number of internship laborers reached 50 people. After three times of the internship, the number increased (maximum three months). It means the company was in need of labor for that position. The apprenticeship process that occurs in the company turned out to be completely different with the aim of apprenticeship in accordance with the mandate of the Law. From 50 internship laborers in PT Nanbu, began their first day of work as other workers. No proportion of the introduction of $25 \%$ theory and practice. The internship laborers also allowed to work overtime. What distinguishes with other labor is on the salary and social security were not given.

Abuse of other apprenticeship rules in the field is huge. Given the number of supervisors in the Manpower Office area will not be able to supervise the area with the number of factories that reach thousands. Apprenticeship rules violations or misuse that occurs industrial area of Bekasi, among others:

First, the apprentice must get the theory and practice. But on its application on the first day of the apprenticeship work like any other worker, it makes no difference. For example that has happened in PT NPI industrial area of Bekasi. The results of the interviews with some of the apprentice workers in the PT (20/10/2016) states from the first day they work like other workers. The number of interns as many as 50 people and alternately per three months. Labor becomes vulnerable because it has no guarantee of work security (Stunding, 2011).

Second, the apprenticeship period is a maximum of one year, but some cases show that interns can work beyond the specified time limit and even participate in overtime. Overtime work is refined language became "Extra hours of apprenticeship." As was the case in Karachi, reported by the media solidaritas.net (June 10th 2016) PT Sankhosa Indonesia employ workers over a two-year apprenticeship. 
Third, this system generates actors who seek to benefit from internships. ${ }^{2}$ Work Training Institution (LPK) which distributes labor for the company where work. As the testimony of KA (female, internship worker of PT NPI Bekasi) in solidaritas.net media, with the complicated mechanism, register through BKK School of SMK ITI and accepted in LPK MS but overall have to pay up to 1.3 million IDR.

Fourth, the established industrial relations became unclear. LPK which is the supplier and the company where the work can throw the responsibility if there is a problem for the intern. Normatively the apprenticeship is the responsibility of the LPK, but if there is a problem it can easily wash hands with the pretext that it is a matter of the co..mpany where the work. The abuses described above are new in terms of normative and economical. In terms of political intern labor cannot be unionized because of short apprenticeship time and there is no certainty of work after the time is over. An apprentice also does not possess the power and bargaining position in the presence of the capital owner.

From the various internships in Bekasi, we can see another crucial problem from the apprenticeship system which is the way for cheap labor. Apprentices do not recognize wages or salaries. The language used in purchasing apprentices labor is pocket money. By using "pocket money", the workers seem to work voluntarily and the rewards earned depend on the goodness of the entrepreneur. The owner of capital is not obliged to comply with the minimum wage rules applicable to giving "pocket money" to apprentices.

For example, PT Nanbu Plastic give pocket money to the internship laborers at 2.144 million IDR, (example the slip of pocket money, see Figure 1), whereas the 2016's UMK of Bekasi District 3,261,375 IDR. It means, with

\footnotetext{
${ }^{2}$ Actors who take advantage of the exploitation of workers are usually strong local people who have the influence to become a distributor of energy to the foundation. Further discussion of the actors sees Nordholt (2004).
}

the same productivity as permanent workers, the company could save $1,117,375$, IDR -permonth-per-laborers. If there are 50 internship laborers for a period of one year, then the company efficiently as much as $670,425,000$ IDR. Once finished one year (the maximum limit of internship) companies are looking by asking the LPK to find a new internship laborer. Whereas laborers only get a piece of paper graduation certificate is not yet clear what its usefulness. And there is a contradiction with Law No. 13/2003 that every labor is entitled to get wages in accordance with UMK. The Disnaker of District of Bekasi understand it, but the rules are the regulations of the center so that the local government can not do much.

\begin{abstract}
"Yes indeed, the regulations of internship in fact used by the businessmen to increase the production more efficient in terms of cost. Whereas the purpose of ILO and the Government in implementing the internship program is to increase the capacity of secondary school graduates. Yes, we know what the entrepreneurs own character, so the good intentions of government misused. Such as an internship program to Japan, the internship laborers are paid every month with $10,000,000$ and they were happy with it. Whereas MSE in Japan nearly 50 million rupiahs per month. So, in fact, the entrepreneurs who received huge profits from the apprenticeship."
\end{abstract}

From the pocket money slip above, it can be seen that the salary given is only $1,849,600$ IDR. This amount is far below the Bekasi minimum wages (UMK). The application of apprenticeship with this method only benefits the capitalist and harms the workers.

\section{Labor Market Flexibility: Unemployment Circle}

The result of research in Bekasi industrial area shows that the ideal imagined of LMF 
Figure 1.

Sample Image of the Pocket Money Slip.

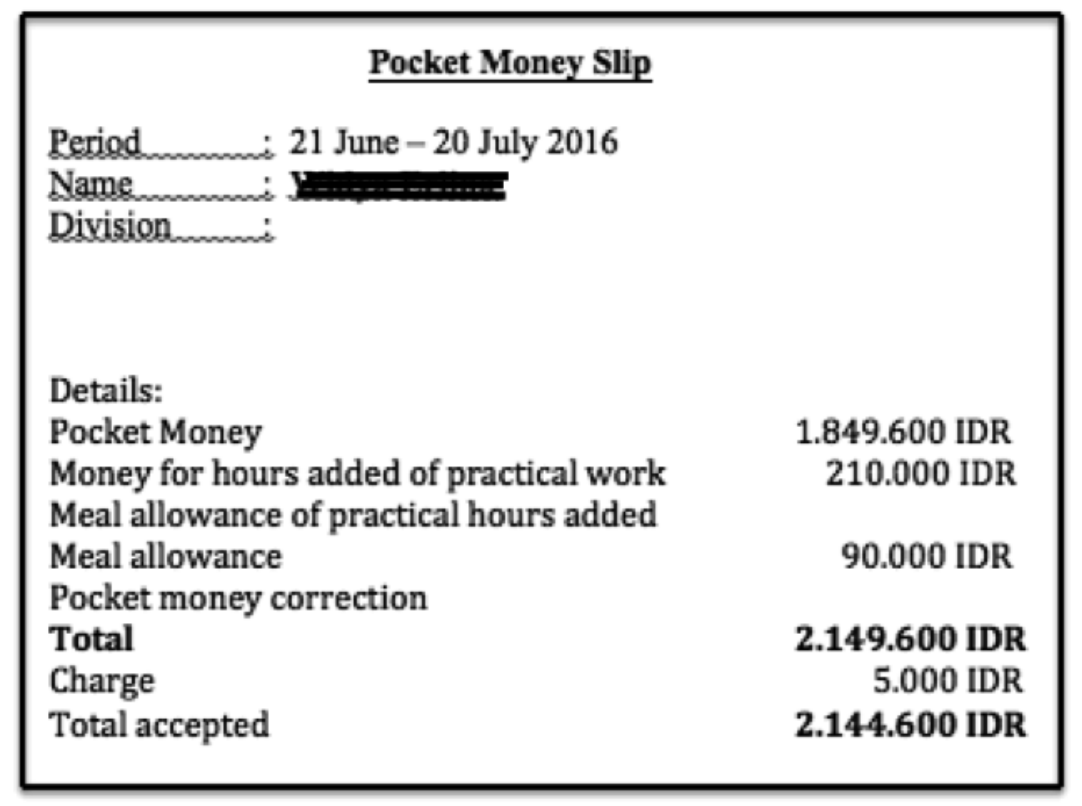

Source: Slip of Pocket Money from Internship labor in PT Nanbu Plastic.

policy proponent is difficult to find in the field. The picture that LMF can reduce the number of unemployed and can absorb labor is utopian. Because based on observations, flexible labor policy of any kind then, in the end, will result in new unemployment. In the productive period, the laborer is contracted with a certain duration so that at a less productive age can be dismissed from his contract and replaced with new workers who are still at the productive age.

Contract work system or PKWT in Law No. 13/2003 maximum applied 2 years and extended one year. So the count of labor is contracted a maximum of 3 years. However, the practice that occurred in the field after 3 years (the maximum number of contracts) workers were asked to re-register from the beginning. So that the period of work that has been run is not counted, so the company does not violate the Act even though it basically uses the contract system more than the specified time limit. The practice is commonly known as "pemutihan". Apprenticeship system also occurs similar practice. As revealed by Wawan in the first sub-chapter, he and others become outsourced laborers for more than nine years. While other friends there are 6 to 7 years into workers whose status is outsourced workers. If it refers to the Manpower Act it should be void by law and become a permanent worker. Outsourced workers who have reached the maximum working limit will be transferred to another factory by the foundation. There are also those who keep working at the company but must register again to the foundation from scratch. That way the work time that has been passed is not counted and if the worker is laid off then do not get severance in accordance with the actual working period.

In the apprenticeship system, there is a practice similar to the contract system as well as outsourcing. Workers of the internship system in accordance with Law No. 13/2003 on employment requires that internship for a maximum of 1 year. If more than the provision then void by law and become permanent workers. But the practice that occurred in the field is much different. As experienced by Sari 
(24) women from Pemalang. Promised by BLK in SMK originally worked in reputable PT in Bekasi industrial area, but Sari was deposited to the foundation of the work supplier. Then get a job with apprentice appointment for 3 months. With a 3-month apprenticeship, the company argues will train and see the performance of the concerned. After 3 months Sari was not appointed as the permanent worker but not renewed internship at PT beginning. The foundation said that the company does not need workers, but there are other companies that need workers. Sari moved to another company with an apprenticeship contract for three months. Until this interview, Sari has moved to three companies. After the third company, Sari was never appointed permanent worker. In the end, since the apprenticeship time is up and the foundation says no other company needs an apprentice then Sari is forced to work as an informal laborer in a small coffee shop around the Industrial area.

LMF practices that occur in the field show no effort to absorb the workforce and reduce unemployment. But with the LMF just rotating the workforce. The LMF policy only forms a reserve circle of the workers' army. There is a rolling between unemployment and temporary workers so that the number of surplus population is relatively maintained. Some cases indicate that after the apprenticeship period is over and not appointed as permanent workers, then the apprentices are then forced to become informal, or informal, laborers of the proletariat (Habibi, 2016), in the vicinity of industrial estates. The informal proletariat, if necessary, may at any time be withdrawn in the capitalist production chain. And the more intense the apprentice's system is, the greater the position of the capital owners in union busting. If workers are divided by work status the working class will not be able to fight its interests as a group (Hadiz, 1997; Hadiz \& Robinson, 2005; Tornquist, 2004; Juliawan, 2011).

\section{LMF impact on trade unions}

The application of LMF in Bekasi also had a negative impact on trade unions. Freedom of association is an illusion. Contract labor, outsourcing and apprenticeship policies make workers reluctant to associate. By looking at the data on the number of workers in association, comparing the number of workers and seeing how many contract workers in the Bekasi Industrial Area and comparing the number of flexible workers who are unionized can find out the detrimental effects of the LMF on the labor movement (Nugroho, 2016, p. 154).

In Bekasi industrial area, there are 5 members of a large confederation (KSPI, KSPSI, SBSI, FPBI, KASBI) 2 a combination of trade unions, and more than 10 independent trade union workers. The largest number of labor unions is still held by SPSI with a total of 94,822 members and then followed by SPMI with a total of 81,739 members representing the yellow union. The large red union is GSPB with 3000 members and SGBN with the number of 500 members. Only the KASBI Confederation with a small mass base in Bekasinya is only around 300 members.

The decline in the number of members can be seen from one of the largest number of unions, FSPMI. In 2014 the total number of members from FSPMI reached 100,873 members, while the data collected by FSPMI in September 2016 decreased to 81,739 members. In 2014 the number of Work Unit Leaders who became the basis of FSPMI totaled 432 factories. Whereas in 2016 the number of factories that became the basis of FSPMI only numbered 304 reduced by more than 100 factories.

Trade union members who are flexible workers from the data obtained from one of the FSPMI members, the Electric Electronics Workers Union as of September 2016, are no more than $30 \%$ of contract workers who are members of the union. Of the 95 PUKs that are the basis of the electronic and electrical sector FSPMI the number of contract workers 
is 28,564 people. Whereas from the number of contract workers who joined the union as many as 8,190 people or only $28 \%$ of the total contract workers. There are not even outsourced workers joined as members.

From the results of the study there is a large influence from the adoption of flexible labor market policies on union density in the Bekasi industrial area. The influence of flexible labor policies on freedom of association or the labor movement is:

1. Differences in work status make workers fragmented and create sectoral ego.

2. There is no guarantee of employment to make flexible workers unwilling to organize.

3. The flexible labor market makes workers trapped in economic behavior.

4. Union busting practices against trade union officials who are flexible workers.

5. Demoralization of flexible workers.

Not all trade unions want to accept members from flexible workers. Yellow labor unions with large members such as the SPSI do not want to accept contract or outsourced laborers as union members. SPMI still wants to accept union members from contract workers but not outsourced workers. Only the red union is willing to accept and fight for flexible workers in earnest. That can be seen from members, advocacy and actions carried out by the union. Yellow labor unions in conducting advocacy and action tend to avoid the issue of contract labor and outsourcing. Advocacy carried out did not add to the problem of violations to contract workers or outsourced workers. SPMI and SPSI after the 2012 action have never again carried out advocacy and championed contract labor and outsourcing.

In the SPSI union, the number of members reached 94,822 out of 218 PUK / factories, none of which consisted of flexible workers. This is because the SPSI does not accept contract workers as members. As said by Abi, a contract worker of PT Indofood, which is one of the large SPSI bases with 1572 members. Abi stated that when she had worked for 1 year she learned that there was a union at the factory, SPSI. When you want to register as a member, the SPSI management at the factory level does not allow contract workers to become members. One of the reasons for the management is that contract workers are not yet clear about the future of their work. If you have been registered as a member and next year the contract is not renewed, it will become a separate obstacle in the union. Therefore the union prioritizes workers to become union members. Contract workers feel discriminated against because of differences in status that are allowed to become members of the union. The impact of flexible labor policies other than labor fragmentation above is the unwillingness of the workers themselves to organize. There is no guarantee that being appointed as a permanent worker after the contract ends makes the worker pursue the maximum target economically at the time of the contract. The average worker is contracted for 2 years and it is not clear whether after the contract ends the contract will be extended or not. This lack of clarity makes workers unwilling to organize. This was explained by the leader of the Bumi Humans PT Nanbu Plastic union, Saiful. Providing awareness of flexible workers about the importance of association is difficult. Because contract workers and apprentices prefer to do overtime rather than associate. Even if there is a problem, the union is the place where workers complain and fight for their rights.

Flexible labor market policies from the description above cause freedom of association guaranteed by the Law to be of no use. There is a contradiction between Law No. 21/2000 concerning freedom of association with flexible work agreements in terms of association. Softly but very effectively makes workers away from the union. So the author uses the terminology of a Trojan horse or Trojan horse. Trojan horse 
in Greek mythology is a strategy used to attack the city of Troy. Attacking carrying a large horse statue in which was filled with soldiers. After successfully entering the city of Troy the troops pretended to lose and retreat, but some horse statues had been left in enemy territory. In the evening the soldiers inside the horse statue came out and viciously killed the Trojan city guards. Soldiers spread to the strategic joints of city defense and troops from outside came to help. Eventually the Trojan city was defeated by the Greek forces.

There are several important points from the results of the analysis of the dangerous system of flexible work on freedom of association. The damaging effects of a flexible work system can be categorized into two, namely the stranglehold in terms of economics and in terms of politics.

1. From an economic standpoint:

a. The absence of a job guarantee makes flexible laborers trapped in the mindset of economism. Limited work contracts make workers as money search engines. The goal is to be able to save after the work contract expires.

b. For outsourced workers, a work contract that is more flexible makes them unable to associate.

c. Internship workers who have to pay to PEA from the beginning of work and work time is only 3 months, when working only oriented at least "return on investment."

2. From a political standpoint:

a. Flexible labor market policies make fragmented workers divided into several strata according to work status.

b. Discrimination of the treatment of different trade unions against flexible workers.

c. Prone to union busting practices from companies that do not like union workers. d. In outsourcing workers industrial relations become unclear.

e. The transfer of the company can occur at any time to outsourced workers so that they cannot associate in one factory.

f. Workers who work at a 3-month limited company make it difficult to associate.

\section{Conclusion}

The ideal imaginations of the liberals proponent LMF policy seems difficult to find its application in the field. Instead of being the solution to lowering the number of unemployed, the LMF policy only roll-over unemployment. That is, LMF only rotates unemployment and does not reduce it. In addition, LMF further lowers the bargaining position of workers so that easily the owners of capital can dismiss unilaterally. Labor unions in Bekasi Industrial area experienced this. Flexible workers who are unionized are replaced by new workers. Workers under LMF become more precarious (Betti, 2016). The number of flexible workers who join the union is decreasing every year. Another threat from LMF is that it is a pretext of cheap wages, especially in the apprenticeship system. In addition, apprentices and other flexible workers do not get the right as permanent workers. The freedom of choice described by liberal theorists is only felt by capitalist, flexible workers do not have the power to choose freely where they can allocate energy. LMF system also gained another (informal) actor who takes apart to pick up the exploitations of labor. Borrowing the Juliawan (2010) term "LMF is extracting labor from it owner". This paper has limitations in capturing trade union struggles against LMF. Almost post Grebek Pabrik in 2012 there was no adequate analysis related to labor resistance to LMF. This becomes an opportunity for further research so that it can mapping the workers' struggle against specific problems, namely LMF. As well as there is no adequate 
explanation regarding the configuration of capitalist relations with the network of informal actors in flexible labor recruitment.

\section{References}

Atkinson, J. (1984). Flexibility, Uncertainty and Manpower Management (Rep. No. 89). Brighton: Institute of Manpower Studies.

Barbieri, P. (2009). Flexible Employment and Inequality in Europe. European Sociological Review, 25(6), 621-628. doi: 10.1093/esr/ jсp020

Beau, A. (2004). Un siècle demplois précaires: Patron-ne-s et salarié-e-s dans le grand commerce, XIXe-XXe siècles. Paris: Payot.

Betti, E. (2016). Precarious work: Norm or exception of capitalism? Historicizing a contemporary debate: A global gendered perspective. In B. Eloisa \& K. Miller (Eds.), The Power of the Norm: Fragile Rules and Significant Exceptions (Vol. XXXV). Vienna, Austria: Institut für die Wissenschaften vom Menschen.

Breman, J., \& Linden, M. V. (2014). Informalizing the economy: The return of the social question at a global level. Development and Change, 45(5), 920-940. doi:10.1111/ dech.12115

Caraway, T. L., Rickard, S. J., \& Anner, M. S. (2012). International negotiations and domestic politics: The case of IMF labor market conditionality. International Organization, 66(01), 27-61. doi: 10.1017/ s0020818311000348

De Benedetti, A. (2006). Il masso di Sisifo. Studi sull'industrializzazione in bilico. Carocci Rome.

De Vito, C. (2017). Labour flexibility and labour precariousness as conceptual tools for the historical study of the interactions amongs labour relations. In K. H. Roth (Ed.), On the Road to Global Labour History. Leiden: BRILL.

Deyo, F., \& Doner, R. (n.d.). Economic governance and flexible production in East Asia. In F. Deyo \& R. Doner (Eds.), Economic governance and the challenge of flexibility in East Asia (pp. 1-32). Oxford: Rowman and Littlefield.

Gilles, S. P. (1994). Staff Papers. International Monetary Fund, 41(4), pp. 624-642.

Habibi, M. (2016). Surplus pekerja di kapitalisme pinggiran: Relasi kelas, akumulasi, dan proletariat informal di Indonesia sejak 1980an. Tangerang Selatan: CV Marjin Kiri.

Hadiz, V. R. (1997). Workers and the state in new order Indonesia. London: Routledge.

Hadiz, V., \& Robison, R. (2005). Neo-liberal reforms and illiberal consolidations: The Indonesian paradox. Journal of Development Studies, 41(2), 220-241. doi: 10.1080/0022038042000309223

Harrod, J., \& O'Brien, R. (2002). Organized labor and the global political economy. In J. Harrod \& R. O'Brien (Eds.), Global unions? Theory and strategies of organized la-bor in the global political economy (pp. 3-28). London: Routledge.

Hefeker, C. (2001). Labor market rigidities and EMU. Journal of Economic Integration, 16(2), 229-244. doi:10.11130/jei.2001.16.2.229

Islam, I. (2000). Employment, labor market and economic recovery in Indonesia: Issues and options (Working paper No. 00/04). Jakarta: UNSFIR.

Juliawan, B. H. (2010). Extracting labor from its owner. Critical Asian Studies, 42(1), 25-52. doi: 10.1080/14672710903537464

Juliawan, B. H. (2011). Street-level politics: Labour protests in post-authoritarian Indonesia. Journal of Contemporary Asia, 41(3), 349-370. doi:10.1080/00472336.2011.582706

Leleux, M. (2015). Aux sources de la précarité: Linstrumentalisation du travail dans le Nord 1848-1914. Villeneuve dAscq: Presses Universitaires du Septentrion.

Linden, M. V. (2014). San Precario: A new inspiration for labor historians. Labor Studies in Working-Class History of the Americas, 11(1), 9-21. doi: 10.1215/15476715-2385372

Livingstone, D. W. (2018). The education-jobs gap: Underemployment or economic democracy. NY, NY: Routledge. 
Lorenzo E. Bernal-Verdugo, Davide Furceri, Dominique Guillaume. 2012. Labor market flexibility and unemployment: New empirical evidence of static and dynamic effects (Working Paper). IMF.

Mather, C. (2004). Contract/agency labour: A threat to our social standards. Brussels: ICEM.

Migdal, J. S. (1988). Strong societies and weak states: State-society relations and state capabilities in the Third World. Princeton (N.J): Princeton University Press.

Mosoetsa, S., Stillermann, J., \& Tilly, C. (2016). Precarious Labor, South and North: An Introduction. In Mosoetsa, S., Stillermann, J., \& Tilly, C., (Ed.), Precarious labor in global perspective, special Issue "International Labour and working-class history", 89, pp. 5-19.

Nordholt, H. (2004). Decentralisation in Indonesia: Less state, more democracy? In John Harriss, Kristian Stokke, \& Olle Tornquist (Ed.), Politicising democracy: The new local politics of democratization. Basingtoke: Palgrave Macmillan.

Nugroho, A. (2016). Relasi industrial pada pasar tenaga kerja fleksibel dan perjuangan buruh menuntut upah layak serta jaminan kerja di kawasan industri Bekasi (Unpublished master's thesis). Yogyakarta: Universitas Gadjah Mada.

Nugroho, A. (2018). Serikat Buruh dalam Pusaran Neoliberalisme: Antara Kontrol Represif dan Ilusi Kebebasan Berserikat. In Pramusinto, A., Kebijakan Publik dalam Pusaran Perubahan
Ideologi: Dari Kuasa Negara ke Dominasi Pasar? Yogyakarta: UGM Press.

Purdy, D. (1988). Social power and the labour market: a radical approach to labour economics. London: Macmillan Education Ltd.

Rodgers, G. (2007). Labour market flexibility and decent work (DESA) (Working Paper No. 47). New York: United Nations Department of Economic and Social Affairs.

Rubery, J. (2003). The organization of employment: An international perspective. Houndmills, Basingstoke, Hampshire; New York, NY: Palgrave Macmillan.

Sidel, J. (2004). Bossism and democracy in the Philippines, Thailand and Indonesia: Towards analternative framework for the study of "local strongmen". In John Harriss, Kristian Stokke, and Olle Tornquist (Ed.), Politicising democracy: The new local politics of democratisation. Basingtoke: Palgrave Macmillan.

Stunding, G. (2011). The precariat: the new dangerous class. London: Bloomsburry.

Tjandraningsih, I., Herawati, R., \& S. (2010). Diskriminatif dan eksploitatif: Praktek kerja kontrak dan outsourcing buruh di sektor industri metal di Indonesia. Bandung, Indonesia: AKATIGA.

Törnquist, O. (2004). Labour and democracy? Reflections on the Indonesian impasse. Journal of Contemporary Asia, 34(3), 377-399. doi: 10.1080/00472330480000171 